\title{
CATIONS (CA, MG, NA, K) IN BOTTOM SEDIMENT OF THE LOWER SILESIAN DAM RESERVOIR
}

\author{
Magdalena Senze ${ }^{1}$, Monika Kowalska-Góralskaํ, Katarzyna Czyż² \\ ${ }^{1}$ Department of Limnology and Fishery, Institute of Animal Breeding, Wrocław University of Environmental and \\ Life Sciences, Norwida 25, 50-375 Wrocław, Polska \\ ${ }^{2}$ Department of Sheep and Fur Animals Breeding, Institute of Animal Breeding, Wrocław University \\ of Environmental and Life Sciences, Norwida 25, 50-375 Wrocław, Polska
}

Link to this article: https://doi.org/10.11118/actaun202068040687

Received: 4. 6. 2020, Accepted: 7. 8. 2020

To cite this article: SENZE MAGDALENA, KOWALSKA-GÓRALSKA MONIKA, CZYŻ KATARZYNA. 2020. Cations (Ca, $\mathrm{Mg}, \mathrm{Na}, \mathrm{K})$ in Bottom Sediment of the Lower Silesian Dam Reservoir. Acta Universitatis Agriculturae et Silviculturae Mendelianae Brunensis, 68(4): 687-698.

\begin{abstract}
The study was conducted on the Stup reservoir and the Nysa Szalona river (Poland). The material was benthic water and sediments. The aim of the study was to evaluate accumulation of $\mathrm{Ca}, \mathrm{Mg}, \mathrm{Na}$ and $\mathrm{K}$ in the sediments. The assessment of studied elements accumulation was based on calculations of the cumulation factor in the sediment. On this basis, an attempt was made to assess the possible impact of the compounds deposited in the sediment on the organisms living in the reservoir and on the change in the composition of water which constitutes the basis for drinking water. It was found that the studied sediments are rich in $\mathrm{Ca}, \mathrm{Mg}$ and $\mathrm{K}$ compounds but relatively poor in sodium compounds. The level of the studied elements in the sediment and water in the annual cycle does not show strong changes and in the relatively stable conditions existing in the reservoir it does not pose a threat to organisms living there. Moreover, it does not adversely affect the composition of water which is obtained for water supply purposes.
\end{abstract}

Keywords: Mg, Na, K, Ca, bottom sediment, water, dam reservoir

\section{INTRODUCTION}

Surface waters occupy a special position in the natural environment and play an important role in its functioning. They are a habitat for plant, animal and bacterial organisms, a source of drinking water for animals and humans. Additionally, they perform an economic role in industry, agriculture and municipal activities. The group of surface waters includes flowing and still waters, and a special type of surface waters are ponds and dam reservoirs constructed for a specific economic or municipal purposes (fishing production, retention, energy and recreation). The role of dam reservoirs in Poland is the most often retention - flood protection and water collection for consumption and industry purposes (Wójcikowska-Kapusta et al., 2018).

The operation of dam reservoirs depends on the current demand, depending on the season the reservoirs are ready for the water filling cycle or already filled with water awaiting its release. As a rule, this type of regulation is carried out in a cyclical manner, but sudden high water levels can be observed occasionally. This often involves rapid and violent discharges of water from the reservoir in order to prepare it for the collection of a new portion of water quickly inflowing from the catchment. Despite the rapid changes observed in the reservoir, the life in the aquatic ecosystem continues in its characteristic way. Although it is sometimes interrupted by rapid changes in water levels, increased flow rates, and the inflow of often lower quality water, the organisms living in these ecosystems adapt to these changes (Komosa, 1999).

Sediments in dam reservoirs are formed over the years, and their thickness is subject to an increase. Mineral and organic particles deposition is a natural 
process, however, it can also be intensified by pollution delivered from the catchment area. The bottom in reservoirs with water flow regulation is uncovered and exposed to the atmospheric conditions. In the so-called operating reservoirs, both the removal of the active surface layer of sediments when the drain is located at the bottom of the basin, and sediments accumulation during the reservoir filling are observed. Also the quantitative composition of the sediment may vary, and all these factors result in the changes in the amount and nature of chemical compounds present in the sediment. Due to more significant role of sorption processes in the reservoir compared to the lakes, the levels of exchangeable $\mathrm{Ca}, \mathrm{Mg}, \mathrm{Na}$ and $\mathrm{K}$ cations (sum of exchangeable bases) determine the quality of water to a greater extent. The sources of these cations are mainly located in the reservoir catchment area. Part of the compounds brought in with water is subject to precipitation and becomes the building element of sediments (Komosa, 1999).

The level of calcium in the Earth's crust amounts to $3.39 \%$, and its main source in surface waters are limestones. Waters with low mineralization level are abundant with calcium ions, while sodium ions predominate in highly mineralized waters. The process of rocks, -mainly aluminosilicates, degradation constitutes another source of $\mathrm{Ca}$ in the waters. The level of $\mathrm{Ca}$ in the bottom sediment is related to the presence of living organisms inhabiting water, their dying and decomposition. Calcium carbonate is the most typical form in which $\mathrm{Ca}$ is bound, and it is much more soluble than calcium sulfate which can also be found in waters (Kubiak et al., 1999).

Magnesium is present in most surface waters, and it originates from limestone, dolomites, magnesites and gypsum leaching, also from plant and animal remains. The proportion of $\mathrm{Mg}$ in magma rocks is in the range of $0.20-24.50 \%$, in sedimentary rocks it is $0.70-8.20 \%$, and this element level in the Earth's crust reaches $1.93 \%$. Mg content in plants is about $1 \%$, and its presence in plants is essential for their proper functioning (Kubiak et al., 1999).

Industry and agriculture are the main anthropogenic sources of $\mathrm{Mg}$ and $\mathrm{Ca}$ in the environment. The presence of $\mathrm{Mg}$ in water is important when it is used for consumption purposes. Hard waters contain higher levels of $\mathrm{Mg}$ compared to soft waters, and the level of $\mathrm{Mg}$ in tap water should be at about $30 \mathrm{mgMg} \cdot \mathrm{dm}^{-3}$. Boiling water to reduce its hardness does not contribute to the loss of $\mathrm{Mg}$ in its composition. The ratio of $\mathrm{Ca}$ to $\mathrm{Mg}$ in waters with mineralization up to $500 \mathrm{mg} \cdot \mathrm{dm}^{-3}$ ranges from $4: 1$ to $2: 1$. When the mineralization degree increases up to $1 \mathrm{~g} \cdot \mathrm{dm}^{-3}$, this ratio is from $2: 1$ to $1: 1$, and with further increase $\mathrm{Mg}$ level exceeds the level of Ca which can be observed in sea waters (Kubiak et al., 1999).

The presence of $\mathrm{Na}$ and $\mathrm{K}$ in water is the result of leaching of sedimentary rocks which are rich in these elements salts. Sodium belongs to the elements that most often occur on the Earth's surface (2.63\% of the Earth's crust). In surface waters it is definitely more often present in the form of $\mathrm{NaCl}$. In anthropogenic drainage basins, $\mathrm{Na}$ and $\mathrm{K}$ also originate from industrial and household sewage or agricultural lands. The ratio of sodium to potassium in surface water amounts to 1:4 (Gomółka and Szaynok, 1997; Kabata-Pendias and Pendias, 1999).

The main sources of $\mathrm{Ca}, \mathrm{Mg}, \mathrm{K}$ and $\mathrm{Na}$ ions for the Stup reservoir include the runoff from agricultural areas, municipal sewage including sewage from public utility sites and small plants from the towns of Bolków and Jawor. The aim of the study was to evaluate the accumulation of exchangeable cations $\mathrm{Ca}, \mathrm{Mg}$, Na and $\mathrm{K}$ in bottom sediments deposited in the basin of the Słup reservoir constructed on the Nysa Szalona River, and on this basis to assess the impact of the compounds deposited in the sediment on animal organisms living in the reservoir and on the quality of water which is a source of drinking water.

\section{MATERIALS AND METHODS}

\section{Research Area}

The study was conducted on the area of the Stup reservoir and the Nysa Szalona River. The reservoir was constructed on the border of the Sudeten Foothills as a result of Nysa Szalona valley damming in an $8.20 \mathrm{~km}$ run in the village of Słup. Construction of the reservoir was performed in the years 1978-1986, and its parameters are as follows: length $2900.00 \mathrm{~m}$, max depth $18.05 \mathrm{~m}$, capacity $31.52 \mathrm{mln}^{3}$. The role of the reservoir is flood prevention and municipal water supply (Szulkowska-Wojaczek and Marek, 1984; Broś, 1995).

The Nysa Szalona River is a third order watercourse, a right-bank tributary of the Kaczawa River, and it flows into it in $53.40 \mathrm{~km}$. The total length is $51.00 \mathrm{~km}$, catchment area $-443.10 \mathrm{~km}^{2}$ of which over $86 \%$ is the catchment area of the Stup reservoir. The Nysa Szalona River collects sewage from the area of the towns of Bolków and Jawor as well as from rural areas located in the catchment (Broś, 1974).

\section{Sampling and Chemical Analysis}

The research material consisted of bottom sediments and benthic water. The samples were collected four times a year: in spring (April), summer (July), autumn (October) and winter (January), from the following research sites (Fig. 1, 2): 1 - Nysa Szalona River above dam reservoir (N:514'57"; E:1608'0"); 2 - Słup dam reservoir in the range of backwater - depth $5 \mathrm{~m}$ (N:515'18”; E:1607'44”); 3 - Słup dam reservoir near the southeastern side - depth 9 m (N:5105’59”; E:1607'51”); 4 - Słup dam

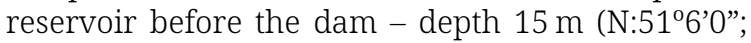
E:166'41”); 5 - Nysa Szalona River below dam reservoir (N:515’53”; E:166'31”). 


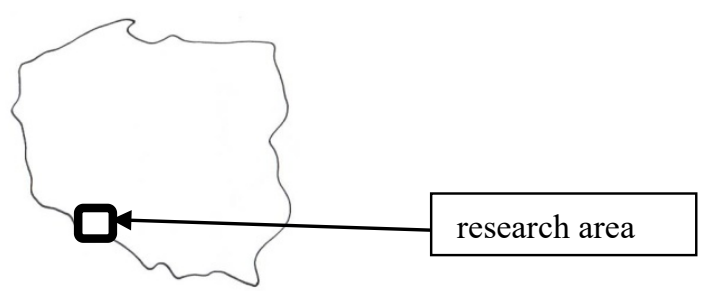

1: Scheme of research area location

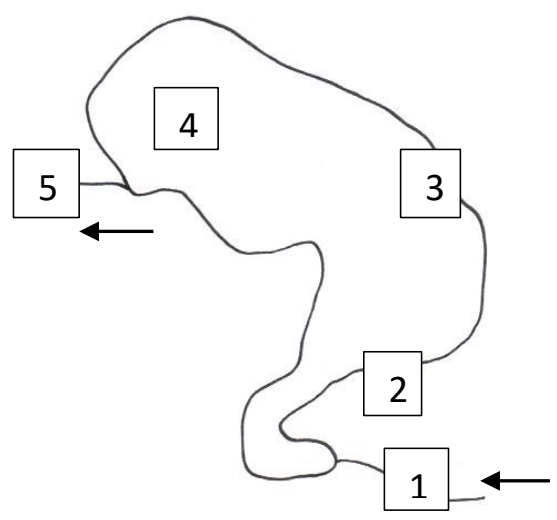

2: Research sites arrangement

Water samples were collected using Ruttner water sampler to polyethylene bottles from a depth of $0.50 \mathrm{~m}$ above the sediment. In the laboratory, the samples were filtered on 0.45 Whatman 1 filters. The content of $\mathrm{Ca}, \mathrm{Mg}, \mathrm{Na}$ and $\mathrm{K}$ was analyzed in raw water by atomic absorption spectrophotometry on Spectra AA-110/220 apparatus of Varian company (PB-10/I 1998). The detection limits $\left(\mathrm{mg} \cdot \mathrm{kg}^{-1}\right)$ were as follows: $\mathrm{Na}-1.000, \mathrm{~K}-5.000, \mathrm{Mg}$ -0.015 , Ca -0.500 . The surface layer of sediments was collected with Ekman's sampler from the same sites from which water was collected. It was dried at room temperature, grinded in a mortar and sieved through a $2 \mathrm{~mm}$ mesh sieve. In the next step, $2 \mathrm{~g}$ air-dry and homogenized sample was weighed in HP-500 Teflon vessel. After an addition of $10 \mathrm{~cm}^{3}$ $\mathrm{HNO}_{3}: \mathrm{HClO}_{4}(3: 1)$ (Sigma - Aldrich) the samples were left for 24 hours at room temperature. Then they were placed in a Mars 5 microwave oven (CEM, USA) and mineralized using 3-stage mineralization process (Tab. I) (Operation manual MARS 5, 1999).

After cooling to room temperature, the mineralysates were transferred to the tubes and diluted with distilled water up to $25 \mathrm{~cm}^{3}$. As in the case of water samples, the levels of $\mathrm{Ca}, \mathrm{Mg}$, $\mathrm{Na}$ and $\mathrm{K}$ were examined in the sediments. The measurement was carried out using the atomic absorption spectrophotometry method with Spectra AA-110/220 from Varian company (PB-10/I 1998). The $\mathrm{pH}$ of water was measured by pH-meter (potentiometric method) (PN-EN ISO 10523:2012), the $\mathrm{pH}$ of sediment was determined in aqueous solution (PN-ISO 10390:1997). The total content of organic matter was determined by weight method during its ignition at $550{ }^{\circ} \mathrm{C}$ in the muffle furnace. The residue of the sample after ignition was taken as the content of mineral compounds (PN-EN 12879:2004). The Concentration Factor (CF) for cations in the sediment was calculated as the ratio of their content in the sediment $\left(\mathrm{C}_{\mathrm{MO}}\right)\left(\mathrm{mg} \cdot \mathrm{kg}^{-1}\right)$ to their concentration in water $\left(\mathrm{C}_{\mathrm{MW}}\right)$ in $\left(\mathrm{mg} \cdot \mathrm{dm}^{-3}\right)$ (Masoud et al., 2005).

$C F=\frac{C_{M O}}{C_{M W}}$,

CF .....concentration factor,

$\mathrm{C}_{\mathrm{MO}}$.....concentration in sediment $\left(\mathrm{mg}^{\cdot} \mathrm{kg}^{-1}\right)$,

$\mathrm{C}_{\mathrm{MW}} \ldots$ concentration in water $\left(\mathrm{mg} \cdot \mathrm{dm}^{-3}\right)$.

\section{Statistical Analysis}

Statistical analyses were performed using R-studio Version 1.1.442- (C) 2009-2018 RStudio. Inc. and Statistica Version 13.3 software. The Shapiro-Wilk test was used to verify the normality of distribution. Due to the distribution of samples deviating from normal one, non-parametric tests were used: Friedman test then Wilcoxon post-hoc test with FDR correction. The results were subjected to principal component analysis (PCA).

\section{RESULTS AND DISCUSSION}

\section{Water and Bottom Sediments - $\mathrm{pH}$}

The mean $\mathrm{pH}$ of benthic water within the reservoir ranged from 7.66 to 7.96 (Tab. II). The pH of Nysa Szalona River water supplying the reservoir was slightly higher and ranged from 7.47 to 7.98, while in water leaving the reservoir it was from 7.67 to 7.97. All the values recorded in the study met the criteria for water aimed at water supply and municipal purposes (Regulation of the Minister of Environment, 2002; Journal of Laws, 2017; Water Law, 2018).

The range of bottom sediment mean $\mathrm{pH}$ within the reservoir was from 7.00 to 7.36 (Tab. II). A slight, however not significant statistically increase in this

I: Scheme 3-stage mineralization in a microwave oven Mars 5

\begin{tabular}{ccccccc}
\hline Stage & Power [w] & Power [\%] & Ramp [min] & Pressure PSI control & Temperature $\left[{ }^{\circ}\right.$ C] & Hold [min] \\
\hline 1 & 300 & 100 & 10 & 70 & 110 & 5 \\
2 & 600 & 100 & 10 & 100 & 140 & 10 \\
3 & 600 & 100 & 15 & 180 & 180 & 15 \\
\hline
\end{tabular}


II: Mean values of benthic water $\left(\mathrm{pH}_{w}\right)$ and bottom sediment $\left(\mathrm{pH}_{s}\right)$

\begin{tabular}{cccccccccc}
\hline \multirow{2}{*}{ Site } & \multicolumn{2}{c}{ Spring } & \multicolumn{2}{c}{ Summer } & \multicolumn{2}{c}{ Autumn } & \multicolumn{2}{c}{ Winter } \\
\cline { 2 - 5 } & $\mathrm{pH}_{\mathrm{w}}$ & $\mathrm{pH}_{\mathrm{s}}$ & $\mathrm{pH}_{\mathrm{w}}$ & $\mathrm{pH}_{\mathrm{S}}$ & $\mathrm{pH}_{\mathrm{w}}$ & $\mathrm{pH}_{\mathrm{s}}$ & $\mathrm{pH}_{\mathrm{w}}$ & $\mathrm{pH}_{\mathrm{s}}$ \\
\hline 1 & $7.77 \pm 0.01$ & $7.35 \pm 0.02$ & $7.98 \pm 0.01$ & $7.33 \pm 0.02$ & $7.55 \pm 0.02$ & $7.32 \pm 0.01$ & $7.47 \pm 0.01$ & $7.38 \pm 0.01$ \\
\hline 2 & $7.87 \pm 0.02$ & $7.19 \pm 0.01$ & $7.88 \pm 0.03$ & $7.14 \pm 0.01$ & $7.83 \pm 0.01$ & $7.04 \pm 0.02$ & $7.70 \pm 0.01$ & $7.14 \pm 0.01$ \\
\hline 3 & $7.92 \pm 0.02$ & $7.24 \pm 0.02$ & $7.95 \pm 0.02$ & $7.15 \pm 0.01$ & $7.86 \pm 0.01$ & $7.00 \pm 0.03$ & $7.68 \pm 0.02$ & $7.05 \pm 0.01$ \\
\hline 4 & $7.69 \pm 0.01$ & $7.20 \pm 0.02$ & $7.96 \pm 0.02$ & $7.36 \pm 0.01$ & $7.85 \pm 0.02$ & $7.35 \pm 0.02$ & $7.66 \pm 0.01$ & $7.04 \pm 0.02$ \\
\hline 5 & $7.67 \pm 0.02$ & $7.70 \pm 0.01$ & $7.97 \pm 0.01$ & $7.73 \pm 0.02$ & $7.83 \pm 0.01$ & $7.38 \pm 0.01$ & $7.67 \pm 0.01$ & $7.02 \pm 0.01$ \\
\hline
\end{tabular}

value with the direction of water flow was observed in summer and autumn, it was subject to a decrease in winter, and in spring the situation in the whole reservoir was stable. The $\mathrm{pH}$ of the Nysa Szalona River sediments collected above the reservoir ranged from 7.32 to 7.38 , while this range at the outflow was on a level of 7.02-7.73.

The $\mathrm{pH}$ values of the examined waters and sediments of the Słup dam reservoir are characteristic for fresh flowing and standing waters of the temperate zones. In other reservoirs in the south-western part of Poland, both in protected and industrialized areas, the $\mathrm{pH}$ values of water and sediment were similar to those recorded for the Słup reservoir (Samecka-Cymerman and Kempers, 1999, 2001, 2004; Samecka-Cymerman et al., 2005; Łojko et al., 2015). Similar values were also found in areas of low anthropopressure in the northeastern Poland, i.e., on the area of Mazurian Lakes (Rafałowska et al., 2014) as well as in retention reservoirs in south-eastern Poland (Jasiewicz and Baran, 2006; Wójcikowska-Kapusta et al., 2018).

\section{Mineral and Organic Compounds}

The content of mineral compounds in the Nysa Szalona sediment was high. It mean value above the reservoir ranged from 98.53 to $98.88 \%$, while for the river leaving the reservoir it was 96.61-98.57\% (Tab. III). Thus, slightly higher mineralization was found in sediments accumulated above the reservoir, which was probably due to the settlement of mineral compounds in the reservoir and the simultaneous removal of organic particles from its basin. The sources of these particles was presumably dead organic matter of plant and animal origin.
Compared to the sediments from the Nysa Szalona River, the level of mineral compounds in the Słup reservoir was lower. A slight increase in the amount of organic matter and loss of mineral compounds was observed within the reservoir in its horizontal profile. The whole range of mineral compounds content for the reservoir was from $88.36 \%$ (site 4 in summer) to $92.56 \%$ (site 2 in autumn).

The variability of mineral compounds content in the sediments above and below the reservoir in the annual cycle was similar at both sites and was in the following order: autumn < summer < spring < winter. At sites 2 and 3 within the reservoir it was as follows: autumn < summer $<$ winter $<$ spring, while at site 3 in front of the dam, which is most strongly subject to changes in the structure of the sediment due to forced water flow down the bottom drain, it was spring < autumn $<$ winter $<$ summer. This variability reflects the operation of the reservoir which is the result of human actions.

Compared to other Polish retention reservoirs, the Słup reservoir should be included into the category of highly mineralized in terms of mineral compounds content. Similar values were recorded, among others, for reservoirs in south-eastern Poland where the level of organic compounds was very low (1.16-3.52\%) (Jasiewicz and Baran, 2006). However, compared to the area of Wielkopolska and Mazury (21.94-40.17\%) where agricultural activity is most probably a strong carrier of organic matter, the values recorded in the Słup reservoir are very low (Sobczyński and Joniak, 2009a, 2009b; Rafałowska et al., 2014). In turn, higher values were also recorded in lake sediments in the coastal belt (11.6\%-32.6\%) (Trojanowski and Antonowicz, 2005).

III: Mean mineral (M) and organic (O) compounds content in the bottom sediment

\begin{tabular}{|c|c|c|c|c|c|c|c|c|}
\hline \multirow{2}{*}{ Site } & \multicolumn{2}{|c|}{ Spring } & \multicolumn{2}{|c|}{ Summer } & \multicolumn{2}{|c|}{ Autumn } & \multicolumn{2}{|c|}{ Winter } \\
\hline & $\mathrm{M}$ & $\mathrm{O}$ & M & 0 & M & $\mathrm{O}$ & M & $\mathrm{O}$ \\
\hline 1 & $98.55 \pm 0.29$ & $1.45 \pm 0.29$ & $98.72 \pm 0.19$ & $1.28 \pm 0.19$ & $98.88 \pm 0.15$ & $1.12 \pm 0.15$ & $98.53 \pm 0.07$ & $1.47 \pm 0.07$ \\
\hline 2 & $91.48 \pm 0.10$ & $8.52 \pm 0.10$ & $92.39 \pm 0.08$ & $7.61 \pm 0.08$ & $92.56 \pm 0.20$ & $7.44 \pm 0.20$ & $92.35 \pm 0.24$ & $7.65 \pm 0.24$ \\
\hline 3 & $89.53 \pm 0.10$ & $10.47 \pm 0.10$ & $90.58 \pm 0.27$ & $9.42 \pm 0.27$ & $90.62 \pm 0.18$ & $9.38 \pm 0.18$ & $89.55 \pm 0.07$ & $10.45 \pm 0.07$ \\
\hline 4 & $92.33 \pm 0.10$ & $7.67 \pm 0.10$ & $88.36 \pm 0.32$ & $11.64 \pm 0.32$ & $90.56 \pm 0.27$ & $9.44 \pm 0.27$ & $89.53 \pm 0.20$ & $10.47 \pm 0.20$ \\
\hline 5 & $97.60 \pm 0.34$ & $2.40 \pm 0.34$ & $98.50 \pm 0.04$ & $1.50 \pm 0.04$ & $98.57 \pm 0.24$ & $1.43 \pm 0.24$ & $96.61 \pm 0.23$ & $3.39 \pm 0.23$ \\
\hline
\end{tabular}




\section{Calcium}

The lowest amounts of $\mathrm{Ca}$ in the sediment throughout the entire research cycle were found in spring and the highest in autumn at each site. In spring, calcium was used by aquatic organisms as a building material and its amount decreased in the sediment. In turn, in the autumn the sediment was enriched by calcium compounds, which was the result of the decomposition of dying water vegetation. The mean lowest Ca content among the sediments collected within the reservoir was $48.3{\mathrm{gCa} \cdot \mathrm{kg}^{-1}}^{-1}$ (Tab. IV), and concurrently the concentration of $\mathrm{Ca}$ in water was $60.27 \mathrm{mgCa} \cdot \mathrm{dm}^{-3}$ (Tab. VIII). In turn, the highest Ca content in the sediment was $140.4 \mathrm{gCa} \cdot \mathrm{kg}^{-1}$ and in water it was $48.97 \mathrm{mgCa} \cdot \mathrm{dm}^{-3}$ (Tab. IV, VIII). A decrease in the level of $\mathrm{Ca}$ in the sediment was observed in every season from site 2 to site 4 in the horizontal profile of the reservoir, i.e., together with the direction of water flow.

In the case of the Nysa Szalona River, higher amounts of $\mathrm{Ca}$ were found in the sediment at the inflow to the reservoir (site 1) and lower in the outflow (site 5) in each research cycle and regardless of the season. Higher amounts of $\mathrm{Ca}$ were noted in the sediment at site 2 compared to site 1 , which is probably a result of slowing down the flow of water in the backwater area and accumulation of larger sedimentary deposits there. A similar relationship was found between site 4 and site 3 , and this is the effect of forced water flow in the reservoir as well as resulting sediment particles transfer. Similar trend was observed in case of sediments collected at the outflow where Ca content was each time higher than in sediments collected by the dam (site 4).

Ca concentration in the water of the Słup reservoir ranged from $40.54 \mathrm{mgCa} \cdot \mathrm{dm}^{-3}$ in summer (site 4) to $77.44 \mathrm{mgCa} \cdot \mathrm{dm}^{-3}$ in winter (Tab. VIII). Generally, Ca level in water indicates the following series of concentrations increasing in subsequent seasons of the year: spring < winter < summer < autumn. When comparing the extreme positions (inflow and outflow) on the Nysa Szalona River, it can be noted that except for winter Ca was retained in the reservoir as evidenced by higher concentrations present in water above the reservoir compared to the site below. Ca content in water has not been included in the standards for water used for consumption purposes, however comparison with the results presented for water production plants in Poland allows to assume that the Ca content in the examined waters does not pose a risk to consumers. For example, the level of calcium in water transferred to the water network in water production plants in

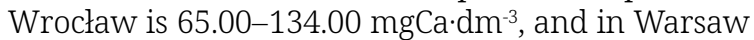
it is 60.20-119.00 $\mathrm{mgCa} \cdot \mathrm{dm}^{-3}$ (mpwik.com.pl, mpwik. wroc.pl).

The accumulation of $\mathrm{Ca}$ within the reservoir expressed by the cumulation factor (CF) values ranged from $\mathrm{CF}=802.1$ (autumn, site 3) to $\mathrm{CF}=2869.3$ (spring, site 2) (Tab. IV). In contrast to the high accumulation of Ca compounds in the bottom sediments of the reservoir, this process was much weaker in the Nysa Szalona River. The range of values was from $\mathrm{CF}=1020.6$ in autumn at site 1 to $\mathrm{CF}=2347.4 \mathrm{in}$ spring at site 5 . A higher accumulation of Ca compounds was observed in the sediment collected at the outflow from the reservoir in spring, summer and autumn compared to the inflow.

Compared to other Polish water reservoirs, similar amounts of $\mathrm{Ca}$ as those recorded in the Stup reservoir were found in the Dobromierz dam reservoir located in its close vicinity. An increase in the amount of Ca compounds was also observed in this reservoir with the direction of water flow (Dąbrowska and Lejcuś, 2012). A similar situation was observed by Ligocka and Burczyk (2018) in Miedwie Lake on the Głowienica River, which like the Słup reservoir is a drinking water reservoir (the city of Szczecin), and by Sobczyński and Joniak (2009a, 2009b) who conducted research in the Wielkopolski National Park.

The sediments of the lakes in the northern part of Poland turned out to be very diverse in terms of Ca content compared to the Słup reservoir. Lower levels of this element were found in the sediments studied by Bojakowska and Sokołowska (1997), while the sediments of Pilwa Lake (Dobskie) subjected to strong agricultural anthropopressure were characterized by amounts similar to those recorded in the Słup reservoir

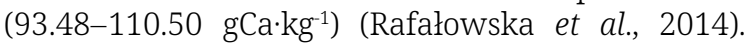
Such values were also noted in the reservoirs of Lublin (35.49-117.6 $\left.\mathrm{gCa} \mathrm{kg}^{-1}\right)$ but significantly lower in the Świętokrzyskie reservoirs (0.84-5.69 gCa $\left.\mathrm{kg}^{-1}\right)$ studied by Wójcikowska-Kapusta et al. (2018). The values falling in the upper range of the Słup

IV: Mean calcium content $\left(\mathrm{gCa} \cdot \mathrm{kg}^{-1}\right)$ and cumulation factor $(\mathrm{CF})$ in the bottom sediment

\begin{tabular}{cccccccccc}
\hline \multirow{2}{*}{ Site } & \multicolumn{2}{c}{ Spring } & \multicolumn{2}{c}{ Summer } & \multicolumn{2}{c}{ Autumn } & \multicolumn{2}{c}{ Winter } \\
\cline { 2 - 10 } & CF & $\bar{x} \pm S D$ & CF & $\bar{x} \pm S D$ & CF & $\bar{x} \pm S D$ & CF & $\bar{x} \pm S D$ \\
\hline 1 & 1692.5 & $135.5 \pm 0.90$ & 1171.2 & $131.4 \pm 0.67$ & 1020.6 & $102.2 \pm 2.85$ & 1851.7 & $128.4 \pm 0.99$ \\
2 & 2869.3 & $140.4 \pm 1.84$ & 2661.6 & $135.12 \pm 0.38$ & 1837.5 & $113.3 \pm 1.67$ & 2207.3 & $127.5 \pm 0.83$ \\
3 & 1219.8 & $73.3 \pm 1.41$ & 939.1 & $69.3 \pm 0.82$ & 802.1 & $48.3 \pm 1.31$ & 993.6 & $68.0 \pm 1.25$ \\
4 & 1577.8 & $90.6 \pm 0.73$ & 2187.2 & $88.46 \pm 0.64$ & 1135.1 & $71.1 \pm 0.75$ & 1222.1 & $94.6 \pm 2.05$ \\
5 & 2347.4 & $119.2 \pm 0.82$ & 1538.7 & $117.49 \pm 1.45$ & 1126.8 & $88.56 \pm 1.13$ & 1490.5 & $107.3 \pm 3.48$ \\
\hline
\end{tabular}


V: Mean magnesium content $\left(g M g \cdot \mathrm{kg}^{-1}\right)$ and cumulation factor (CF) in the bottom sediment

\begin{tabular}{|c|c|c|c|c|c|c|c|c|}
\hline \multirow{2}{*}{ Site } & \multicolumn{2}{|c|}{ Spring } & \multicolumn{2}{|c|}{ Summer } & \multicolumn{2}{|c|}{ Autumn } & \multicolumn{2}{|c|}{ Winter } \\
\hline & $\mathrm{CF}$ & $\bar{x} \pm S D$ & $\mathrm{CF}$ & $\bar{x} \pm S D$ & $\mathrm{CF}$ & $\bar{x} \pm S D$ & $\mathrm{CF}$ & $\bar{x} \pm S D$ \\
\hline 1 & 414.7 & $7.325 \pm 0.0015$ & 215.6 & $8.983 .1 \pm 0.0010$ & 265.3 & $6.973 \pm 0.0017$ & 471.0 & $8.174 \pm 0.0012$ \\
\hline 2 & 660.9 & $8.407 \pm 0.0013$ & 590.5 & $9.225 \pm 0.0012$ & 470.2 & $7.955 \pm 0.0012$ & 706.4 & $10.426 \pm 0.0010$ \\
\hline 3 & 568.3 & $8.296 \pm 0.0041$ & 499.0 & $9.521 \pm 0.0011$ & 554.2 & $8.856 \pm 0.0027$ & 738.7 & $11.255 \pm 0.0016$ \\
\hline 4 & 642.8 & $9.121 \pm 0.0017$ & 986.4 & $10.275 \pm 0.0017$ & 456.3 & $7.743 \pm 0.0016$ & 559.3 & $12.128 \pm 0.0010$ \\
\hline 5 & 517.3 & $7.025 \pm 0.0013$ & 331.8 & $7.202 \pm 0.0005$ & 371.8 & $6.054 \pm 0.0012$ & 568.4 & $8.612 \pm 0.0012$ \\
\hline
\end{tabular}

reservoir and slightly higher were found for the sediments from Dołgie Wielkie Lake (area of strict protection) (Trojanowski and Antonowicz, 2005).

Lower values were recorded for the standing water reservoirs of central Poland, e.g. anthropogenic lakes studied by Samecka-Cymerman and Kempers (2001, 2004), and especially for flowing waters of southern Poland (Samecka-Cymerman and Kempers, 1999, 2003; Łojko et al., 2015). Low Ca contents in sediments were also noted in other reservoirs in southern Poland, like Dziećkowice, Piaseczno, Krempna and Zesławice, Dobczyce (Jasiewicz and Baran, 2006; Reczyński et al., 2006; Szarek-Gwiazda et al., 2006; Biel and Pasieczna, 2012).

To sum up, the level of calcium in the water and sediments of the Słup reservoir and the Nysa Szalona River is so low that it does not pose a threat to aquatic organisms living in its basin. These are conditions conducive to the existence of aquatic plants and animals, and at the same time the concentration of calcium is so safe that water obtained from the reservoir can be used by water production plants.

\section{Magnesium}

The mean $\mathrm{Mg}$ content in sediments within the reservoir ranged from 7.743 to $12.128 \mathrm{gMg} \cdot \mathrm{kg}^{-1}$ (Tab. V). Both values were recorded at site 4 before the dam. In turn, the mean concentration of $\mathrm{Mg}$ in the reservoir water ranged from 10.42 to $21.68 \mathrm{mgMg} \cdot \mathrm{dm}^{-3}$ (Tab. VIII). An increase in $\mathrm{Mg}$ content in the sediment in the horizontal profile of the reservoir was observed in spring, summer and winter, which may be related to the uptake of magnesium by the aquatic vegetation, which abundantly overgrows the upper part of the reservoir. A slight decrease was observed in autumn. An increase in magnesium concentration with the direction of water flow was only noted in spring and winter. The values decreased in summer (magnesium is taken up by aquatic plants) and no changes were observed in autumn.

The content of magnesium in the water of the Nysa Szalona river ranged from 13.58 to $41.66 \mathrm{mgMg} \cdot \mathrm{dm}^{-3}$ (Tab. VIII). Higher concentrations of $\mathrm{Mg}$ were found above the reservoir in each season of the year compared to the site below the reservoir, which indicates that $\mathrm{Mg}$ compounds are deposited in the reservoir basin. A similar relationship was also observed for bottom sediments. The whole range of magnesium content in bottom sediments of the Nysa Szalona River ranged from $6.053 \mathrm{mgMg} \cdot \mathrm{dm}^{-3}$ in autumn below the reservoir to $8.984 \mathrm{mgMg} \cdot \mathrm{dm}^{-3}$ in summer above the reservoir (Tab. V).

The accumulation of $\mathrm{Mg}$ in the Słup reservoir sediment expressed in the value of the cumulation factor $\mathrm{CF}$ increased in summer with the direction of water flow, and decreased in the other seasons of the year. The whole range of values was from $\mathrm{CF}=456.3$ (site 4 in autumn) to $\mathrm{CF}=986.4$ (site 4 in summer) (Tab. V).

A comparison of the two extreme sites on the Nysa Szalona River (inflow and outflow from the reservoir) indicates that higher accumulation occurs at the outflow regardless of the season of the year. The range of these values was from $\mathrm{CF}=215.6$ in summer to $\mathrm{CF}=568.4$ in winter (Tab. V).

The waters of the reservoir feed the water supply system of the area of the city of Legnica and in accordance with the standards applicable to drinking water (range: 7-125 $\mathrm{mgMg} \cdot \mathrm{dm}^{-3}$ ) are suitable for the use (Ministry of Health, 2017; Water Law Act 2018). The magnesium content of the examined components met certain standards, so it does not pose a threat to the organisms living in the reservoir.

The level of $\mathrm{Mg}$ in the sediments studied was within the range recorded for the Mazurian lakes subjected to agricultural anthropopressure (6.48-11.05 gMg.kg-1) (Rafałowska et al., 2014). The catchment area of the Słup reservoir is also agricultural in nature and therefore it can be assumed that the amount of $\mathrm{Mg}$ is similar. This is also the level recorded in Dołgie Wielkie Lake (area of the Słowiński National Park) where the values were similar but with an upward trend (Trojanowski and Antonowicz, 2005). However, most of the still water reservoirs studied in Poland are characterized by a slightly lower level of $\mathrm{Mg}$ in bottom sediments. These values are not very low compared to the Słup reservoir but remain within its lower limits (Bojakowska and Sokołowska, 1997; Samecka-Cymerman and Kempers, 1999, 2001, 2003, 2004; Jasiewicz and Baran, 2006; SzarekGwiazda et al., 2006; Biel and Pasieczna, 2012; Dąbrowska and Lejcuś, 2012; Łojko et al., 2015; Ligocka and Burczyk, 2018; Wójcikowska-Kapusta et al., 2018). 
VI: Mean potassium content $\left(\mathrm{gK} \cdot \mathrm{kg}^{-1}\right)$ and cumulation factor (CF) in the bottom sediment

\begin{tabular}{|c|c|c|c|c|c|c|c|c|}
\hline \multirow{2}{*}{ Site } & \multicolumn{2}{|c|}{ Spring } & \multicolumn{2}{|c|}{ Summer } & \multicolumn{2}{|c|}{ Autumn } & \multicolumn{2}{|c|}{ Winter } \\
\hline & $\mathrm{CF}$ & $\bar{x} \pm S D$ & $\mathrm{CF}$ & $\bar{x} \pm S D$ & $\mathrm{CF}$ & $\bar{x} \pm S D$ & $\mathrm{CF}$ & $\bar{x} \pm S D$ \\
\hline 1 & 107.5 & $0.854 \pm 0.0015$ & 62.6 & $0.615 \pm 0.0010$ & 243.1 & $1.045 \pm 0.0010$ & 184.3 & $1.117 \pm 0.0069$ \\
\hline 2 & 545.9 & $2.928 \pm 0.0510$ & 583.8 & $3.690 \pm 0.0010$ & 583.4 & $3.592 \pm 0.0011$ & 280.4 & $2.803 \pm 0.2438$ \\
\hline 3 & 719.5 & $3.624 \pm 0.1661$ & 492.9 & $2.967 \pm 0.0012$ & 822.5 & $2.977 \pm 0.0103$ & 306.2 & $3.061 \pm 0.0447$ \\
\hline 4 & 873.2 & $4.537 \pm 0.0221$ & 648.4 & $4.007 \pm 0.0038$ & 1059.5 & $3.983 \pm 0.0015$ & 453.1 & $4.532 \pm 0.0429$ \\
\hline 5 & 249.0 & $1.352 \pm 0.0013$ & 86.91 & $0.549 \pm 0.0010$ & 161.74 & $0.556 \pm 0.0017$ & 334.9 & $2.066 \pm 0.0013$ \\
\hline
\end{tabular}

\section{Potassium}

The lowest mean $\mathrm{K}$ content within the reservoir was found in the sediment at site 2 in winter $\left(2.803 \mathrm{gK} \cdot \mathrm{kg}^{-1}\right)$, while at the same time K concentration

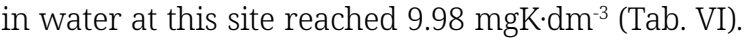
The highest level of $\mathrm{K}$ concentration in water was $10.00 \mathrm{mgK} \cdot \mathrm{dm}^{-3}$ and it was found at site 4 in winter. An increase in the amount of $\mathrm{K}$ in the bottom sediment in the horizontal profile of the reservoir was observed during the whole study cycle together with the direction of water flow towards the dam which is undoubtedly related to mineral particles movement.

Significantly lower amounts of $\mathrm{K}$ were found in the sediments collected at the sites located on the Nysa Szalona River above and below the reservoir compared to the reservoir samples. The range of values was from $0.549 \mathrm{gK} \cdot \mathrm{kg}^{-1}$ at site 5 in summer to $2.066 \mathrm{gK} \cdot \mathrm{kg}^{-1}$ at site 5 in winter (Tab. VI). The process of $\mathrm{K}$ compounds removing from the reservoir was observed in spring and winter which is evidenced by lower $\mathrm{K}$ contents at the inflow to the reservoir than at the outflow. In the summer and autumn season, $\mathrm{K}$ remained in the reservoir sediment, which can be explained by the intake of potassium by aquatic plants.

Potassium concentration in the reservoir water ranged from $3.62 \mathrm{mgK} \cdot \mathrm{dm}^{-3}$ (site 3 , autumn) to $10.00 \mathrm{mgK} \cdot \mathrm{dm}^{-3}$ (site 4 , winter) (Tab. VIII). K content in the Nysa Szalona River ranged from $3.44 \mathrm{mgK} \cdot \mathrm{dm}^{-3}$ (site 5, autumn) to $9.82 \mathrm{mgK} \cdot \mathrm{dm}^{-3}$ (site 1 , summer). In the horizontal profile of the reservoir, $\mathrm{K}$ content decreased with the direction of water flow in spring, summer and autumn. No differences were found in winter. This relationship can be explained by the sedimentation process of the sediment particles in the reservoir and the extraction of potassium from the substrate and water by aquatic plants. This is also reflected in the tendency to retain $\mathrm{K}$ in the reservoir as evidenced by the higher values recorded above and below the reservoir. Potassium concentration in water is not included in the standards for drinking water but the recorded level is so low that it is not likely to pose a risk to consumers. The potassium content of water and bottom sediments remained low throughout the research cycle, but sufficient for aquatic organisms to be able to use it to meet their living needs.
The accumulation of $\mathrm{K}$ within the reservoir expressed by the cumulation factor (CF) values ranged from $\mathrm{CF}=280.4$ (winter, site 2) to $\mathrm{CF}=1059.5$ (autumn, site 4), in contrast to the high accumulation of $\mathrm{K}$ compounds in the sediment of the reservoir (Tab. VI). This process intensity was much lower in the Szalona Nysa River, where the range of values was from $\mathrm{CF}=62.60$ in summer at site 1 to $\mathrm{CF}=334.90$ in winter at site 5 . A higher accumulation of $\mathrm{K}$ compounds was observed in the sediment collected at the outflow from the reservoir in spring, summer and winter compared to the inflow.

Potassium content in the sediments of the Słup lowland reservoir is characteristic for the sediments of the standing water reservoirs and supplying them flowing waters located in almost all of Poland (Samecka-Cymerman and Kempers, 2004; Jasiewicz and Baran, 2006; Szarek-Gwiazda et al., 2006; Dąbrowska and Lejcuś, 2012; Rafałowska et al., 2014; Łojko et al., 2015; Ligocka and Burczyk, 2018; Wójcikowska-Kapusta et al., 2018). Certainly, there are reservoirs poorer in $\mathrm{K}$ compounds but there are definitely fewer of them, and they represent a protected but also strongly anthropogenic catchment area (Samecka-Cymerman and Kempers, 1999, 2001, 2003; Reczyński et al., 2006).

\section{Sodium}

The lowest mean Na content in the sediment of the reservoir $\left(0.920 \mathrm{mgNa} \cdot \mathrm{kg}^{-1}\right)$ was found in autumn at site 2 (Tab. VII). There were few sodium compounds at this site at all seasons. Probably the inflow of water from the Nysa Szalona River moves the particles to further parts of the reservoir. The sodium concentration in water there was $7.96 \mathrm{mgNa} \cdot \mathrm{dm}^{-3}$ (Tab. VIII). The maximum value $\left(5.680 \mathrm{mgNa} \cdot \mathrm{kg}^{-1}\right)$ was recorded in the summer in the sediment also collected at site 3 . At sites 3 and 4 , the values were similar at all seasons of the year, which indicates mixing of water within these sites. Sodium concentration in the water at this site was $12.63 \mathrm{mgNa} \cdot \mathrm{dm}^{-3}$. The amount of $\mathrm{Na}$ in the sediment in the reservoir was found to increase along with the direction of water flow and the phenomenon of $\mathrm{Na}$ deposition was observed in spring and summer, while the removal of $\mathrm{Na}$ from the reservoir was noted in autumn and winter. 
VII: Mean sodium content $\left(g N a \cdot \mathrm{kg}^{-1}\right)$ and cumulation factor $(\mathrm{CF})$ in the bottom sediment

\begin{tabular}{|c|c|c|c|c|c|c|c|c|}
\hline \multirow{2}{*}{ Site } & \multicolumn{2}{|c|}{ Spring } & \multicolumn{2}{|c|}{ Summer } & \multicolumn{2}{|c|}{ Autumn } & \multicolumn{2}{|c|}{ Winter } \\
\hline & $\mathrm{CF}$ & $\bar{x} \pm S D$ & $\mathrm{CF}$ & $\bar{x} \pm S D$ & $\mathrm{CF}$ & $\bar{x} \pm S D$ & $\mathrm{CF}$ & $\bar{x} \pm S D$ \\
\hline 1 & 0.031 & $0.520 \pm 0.0081$ & 0.023 & $0.467 \pm 0.0125$ & 0.024 & $0.361 \pm 0.0163$ & 0.025 & $0.453 \pm 0.0124$ \\
\hline 2 & 0.082 & $0.990 \pm 0.0009$ & 0.107 & $1.391 \pm 0.0163$ & 0.114 & $0.920 \pm 0.0082$ & 0.117 & $2.560 \pm 0.0294$ \\
\hline 3 & 0.285 & $3.241 \pm 0.0216$ & 0.449 & $5.680 \pm 0.0654$ & 0.574 & $4.573 \pm 0.0980$ & 0.230 & $4.251 \pm 0.0082$ \\
\hline 4 & 0.276 & $3.240 \pm 0.0216$ & 0.391 & $5.203 \pm 0.0205$ & 0.575 & $5.130 \pm 0.0081$ & 0.237 & $5.066 \pm 0.0402$ \\
\hline 5 & 0.022 & $0.283 \pm 0.0449$ & 0.021 & $0.286 \pm 0.0047$ & 0.054 & $0.533 \pm 0.0047$ & 0.082 & $1.463 \pm 0.1798$ \\
\hline
\end{tabular}

VIII: Content of $\mathrm{K}, \mathrm{Na}, \mathrm{Mg}$ and $\mathrm{Ca}\left(\mathrm{mg} \cdot \mathrm{dm}^{-3}\right)$ in benthic water

\begin{tabular}{|c|c|c|c|c|c|c|c|c|c|c|c|c|c|c|c|c|}
\hline \multirow{2}{*}{ Site } & \multicolumn{4}{|c|}{$\mathrm{K}$} & \multicolumn{4}{|c|}{$\mathrm{Na}$} & \multicolumn{4}{|c|}{$\mathrm{Mg}$} & \multicolumn{4}{|c|}{$\mathrm{Ca}$} \\
\hline & SP & $\mathrm{SM}$ & A & $\mathrm{W}$ & SP & $\mathrm{SM}$ & $\mathrm{A}$ & $\mathrm{W}$ & SP & $\mathrm{SM}$ & $\mathrm{A}$ & $\mathrm{W}$ & SP & $\mathrm{SM}$ & A & $\mathrm{W}$ \\
\hline 1 & 7.94 & 9.82 & 4.30 & 6.06 & 16.54 & 20.62 & 14.73 & 17.86 & 17.66 & 41.66 & 26.29 & 17.36 & 80.09 & 112.19 & 100.18 & 63.35 \\
\hline 2 & 5.36 & 6.33 & 6.17 & 9.99 & 12.09 & 13.01 & 8.06 & 21.62 & 12.72 & 15.62 & 16.92 & 14.76 & 48.97 & 50.79 & 61.69 & 57.83 \\
\hline 3 & 5.04 & 6.02 & 3.62 & 9.98 & 1 & 1 & 7.96 & 18.47 & 0 & 08 & 15.98 & 24 & 60.18 & 73.98 & 60.27 & 68.48 \\
\hline 4 & 5.20 & 6.18 & 3.76 & 10.00 & 11.72 & 13.32 & 8.92 & 21.37 & 14.19 & 10.42 & 16.97 & 21.68 & 57.40 & 40.54 & 62.62 & 77.44 \\
\hline 5 & 5.43 & 6.32 & 3.44 & 6.17 & 12.66 & 13.54 & 9.85 & 17.77 & 13.58 & 21.71 & 16.65 & 15.15 & 50.83 & 76.43 & 78.61 & 72.13 \\
\hline mean & 5.79 & 6.93 & 4.26 & 8.44 & 12.88 & 14.62 & 9.90 & 19.42 & 14.55 & 21.69 & 18.56 & 16.84 & 59.49 & 70.79 & 72.67 & 67.85 \\
\hline
\end{tabular}

SP - spring, SM - summer, A - autumn, $\mathrm{W}$ - winter

Sodium concentration in the Nysa Szalona River water ranged from $9.85 \mathrm{mgNa} \cdot \mathrm{kg}^{-1}$ (site 5 in autumn) to $20.62 \mathrm{mgNa} \cdot \mathrm{kg}^{-1}$ (site 1 in summer) and in the reservoir it was from $7.96 \mathrm{mgNa} \cdot \mathrm{kg}^{-1}$ (site 3 in autumn) to $21.62 \mathrm{mgNa} \cdot \mathrm{kg}^{-1}$ (site 2 in winter) (Tab. VIII). According to the Regulation of the Minister of Health on the quality of water intended for human consumption, the standard is $200 \mathrm{mgNa} \cdot \mathrm{kg}^{-1}$ and therefore the sodium concentration in the examined waters does not pose a hazard to water users (Ministry of Health, 2017; Water Law Act 2018).

The range of values of the cumulation factor within the reservoir was from $\mathrm{CF}=0.082$ in spring at site 2 to $\mathrm{CF}=0.575$ in autumn at site 4 (Tab. VII), whilefor Nysa Szalona river the range was from $\mathrm{CF}=0.021$ (site 5 in summer) to $\mathrm{CF}=0.08$ (site 5 in winter).

The presence of $\mathrm{Na}$ in the bottom sediments of the Słup reservoir was at a lower level compared to the samples collected in different parts of Poland in areas under the influence of intensive agricultural or industrial management and in protected areas. However a tendency to increase the level of $\mathrm{Na}$ in the reservoir sediment together with the direction of water flow in the horizontal profile can be noted (Jasiewicz and Baran, 2006; Rafałowska et al., 2014; Łojko et al., 2015; Dąbrowska and Lejcuś, 2017; Ligocka and Burczyk, 2018; Wójcikowska-Kapusta et al., 2018).

The level of sodium in water and bottom sediments, like the previously discussed cations, was kept within safe limits both for people using tap water and for organisms living in the water reservoir.
In surface water, as mineralization increases, magnesium ions also prevail over calcium ions. However, in low-mineralized waters, the observed high prevalence of calcium compounds may result from the construction of bottom sediments. The potassium/sodium ratio in unpolluted waters is $1: 4$, and with increasing pollution the ratio also increases (Gomółka and Szaynok, 1997). In order to check whether the examined waters are unpolluted, the ratio of these compounds to each other was determined. The ratio of $\mathrm{Ca}: \mathrm{Mg}, \mathrm{Ca}: \mathrm{K}$ and $\mathrm{Ca}: \mathrm{Na}$ in the studied bottom sediments was highest at the sites above and below the reservoir (Tab. IX). Within the reservoir, the values were lower and decreased with the direction of water flow. A similar trend was observed in the benthic water but the difference in values was much smaller (Tab. IX).

Compared to the Brody Iłżeckie reservoir on the Kamienna River in the Świętokrzyskie Province studied by Wójcikowska-Kapusta et al. (2018), the relationships between the metals studied are quite variable. The $\mathrm{Ca}: \mathrm{Mg}$ ratio was $0.9-8.85$, i.e., it was in a similar range as in the Stup reservoir. The $\mathrm{Ca}: \mathrm{K}$ ratio (0.67-5.35) was lower than in the Słup reservoir. The ratios of Ca: $\mathrm{Mg}$ was 28.05-57.36 and $\mathrm{Ca}: \mathrm{K}$ (22.15-57.09) were much higher than in the Słup reservoir.

Differences between data pairs were determined, and no differences were observed between season or site and $\mathrm{K}$ and $\mathrm{Na}$ content in sediments (KS and NaS) (Tab. X). Interestingly, no differences in variables distributions were observed between $\mathrm{K}$ and $\mathrm{Na}$ content either. Spearman correlation 
between the examined parameters demonstrated a high positive correlation between $\mathrm{Mg}$ and $\mathrm{Na}$ in sediment and $\mathrm{Na}$ and $\mathrm{K}$ in water (Tab. X). A high negative correlation was found between $\mathrm{Mg}$ in sediment and $\mathrm{pH}, \mathrm{Ca}$ in sediment and $\mathrm{Na}$ in sediment. The PCA (Principal component analysis) analysis taking into account the season of the year showed the biggest differences between autumn and winter (Fig. 3). However, that the sites 3 and 4 are the most similar to each other and differ significantly from other sites (Fig. 4). The significance of the correlation are presented in Fig. 5 which explains more than $73 \%$ of the examined cases.

IX: Ratio between particular metals

\begin{tabular}{|c|c|c|c|c|c|c|}
\hline \multirow{2}{*}{ Site } & \multicolumn{2}{|c|}{$\mathrm{Ca}: \mathrm{Mg}$} & \multicolumn{2}{|c|}{$\mathrm{Ca}: \mathrm{K}$} & \multicolumn{2}{|c|}{$\mathrm{Ca}: \mathrm{Na}$} \\
\hline & Water & Sediment & Water & Sediment & Water & Sediment \\
\hline 1 & 15.82 & 3.51 & 136.99 & 12.87 & 276.39 & 5.19 \\
\hline 2 & 14.34 & 3.65 & 39.68 & 7.87 & 88.52 & 4.00 \\
\hline 3 & 6.83 & 4.05 & 20.51 & 10.66 & 14.59 & 5.21 \\
\hline 4 & 8.78 & 3.76 & 20.20 & 9.47 & 18.49 & 4.30 \\
\hline 5 & 14.97 & 4.14 & 95.60 & 13.01 & 168.52 & 5.17 \\
\hline
\end{tabular}

X: Spearman's correlations between tested parameters, sites and seasons with bold p-value $<0.01$

\begin{tabular}{|c|c|c|c|c|c|c|c|c|c|c|}
\hline rho & pHH & pHS & $\mathrm{KH}$ & KS & $\mathrm{NaH}$ & $\mathrm{NaS}$ & $\mathrm{MgH}$ & $\mathrm{MgS}$ & $\mathrm{CaH}$ & $\mathrm{CaS}$ \\
\hline pHS & 0.1475 & & & & & & & & & \\
\hline $\mathrm{KH}$ & - & - & & & & & & & & \\
\hline KS & - & - & 0.0427 & & & & & & & \\
\hline $\mathrm{NaH}$ & - & - & 0.7983 & -0.2140 & & & & & & \\
\hline $\mathrm{NaS}$ & 0.2157 & - & - & 0.7645 & - & & & & & \\
\hline $\mathrm{MgH}$ & 0.0178 & 0.0713 & 0.1589 & -0.4067 & 0.2627 & - & & & & \\
\hline MgS & 0.0834 & - & 0.5761 & 0.6086 & 0.4028 & 0.6884 & - & & & \\
\hline $\mathrm{CaH}$ & - & 0.1072 & 0.1213 & -0.5565 & 0.3469 & - & 0.8230 & - & & \\
\hline $\mathrm{CaS}$ & - & 0.2452 & 0.3869 & -0.3789 & 0.3849 & - & 0.0473 & - & - & \\
\hline Season & - & - & 0.2505 & 0.0284 & 0.3951 & 0.1618 & 0.2669 & 0.2634 & 0.2974 & - \\
\hline Site & 0.0657 & 0.1171 & - & 0.1460 & - & 0.2025 & - & - & - & - \\
\hline
\end{tabular}

Statistically significant values at $\mathrm{P}<0.05$, parameters with letter $\mathrm{H}$ refer to water with letter $\mathrm{S}$ refer to sediment

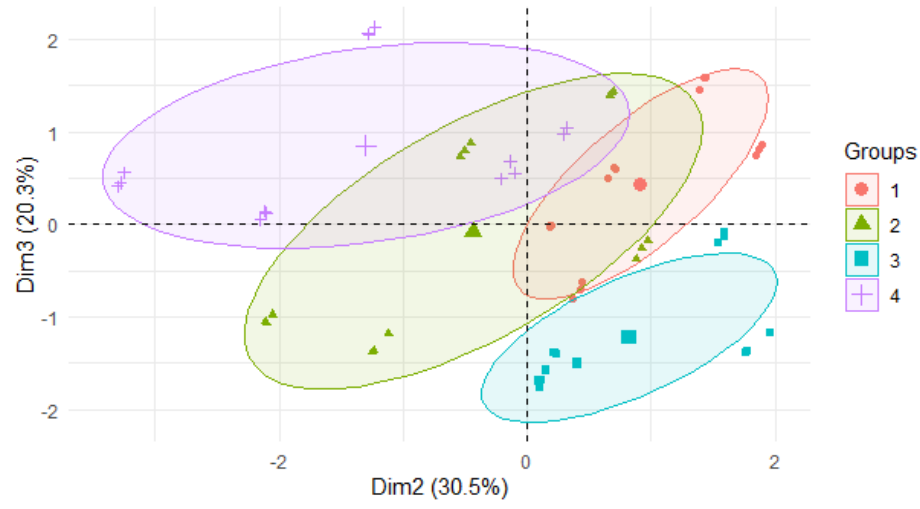

3: PCA analysis taking into account the influence of the season on the examined parameters ( $\mathrm{Na}, \mathrm{Ca}, \mathrm{K}, \mathrm{Mg}$ ) (group: 1 - spring, 2 - summer, 3 - autumn, 4 - winter) 


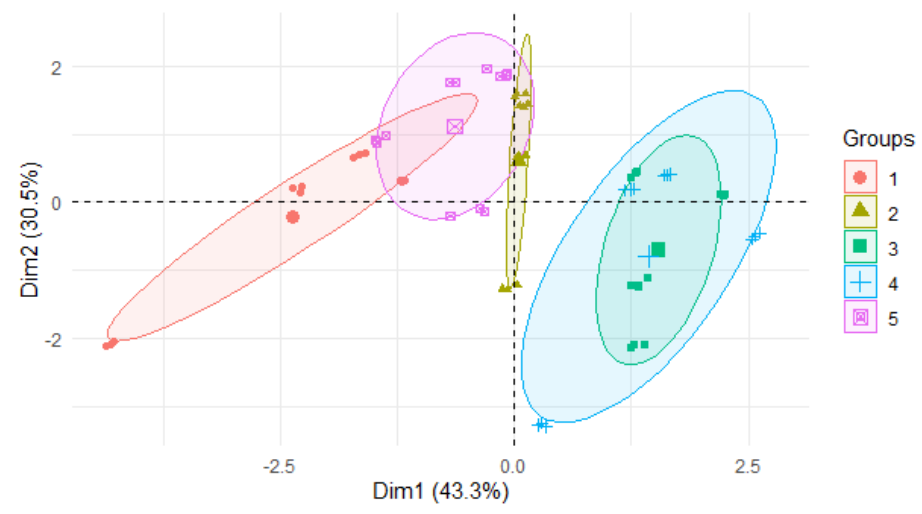

4: PCA analysis taking into account the impact of the site on the examined parameters ( $\mathrm{Na}, \mathrm{Ca}, \mathrm{K}, \mathrm{Mg}$ ) (group number is the site number)

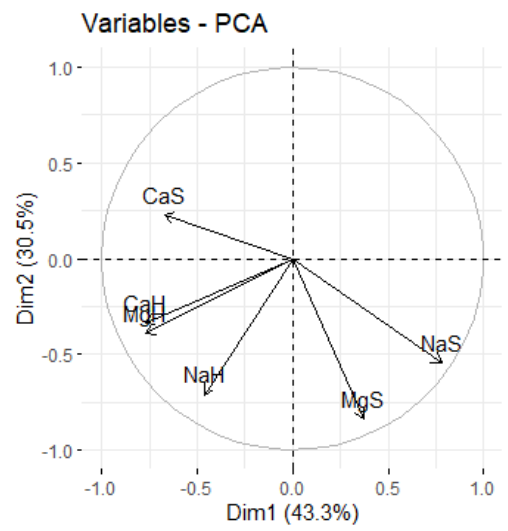

5: Ordination of the five study sites by PCA based on concentrations of elements in water sediments and projection of the concentration of $\mathrm{Na}, \mathrm{Ca}, \mathrm{Mg}$, K in water and in sediments

\section{CONCLUSION}

It can be concluded on the basis of the study conducted on water and bottom sediments of the Stups dam reservoir and the Nysa Szalona River that the water environment is moderately loaded with Ca, $\mathrm{Mg}$, $\mathrm{K}$ and $\mathrm{Na}$ compounds. The composition of the reservoir sediments is a resultant of natural and anthropogenic conditions occurring in the direct and indirect catchment area.

In the water above the Nysa Szalona river and the Słup reservoir, the lowest concentrations were recorded for $\mathrm{K}$ and the highest for Ca according to the following series: $\mathrm{K}<\mathrm{Na}<\mathrm{Mg}<\mathrm{Ca}$.

Evaluation of the accumulation of the elements analyzed based on the cumulation factor (CF) in the bottom sediment indicates that the they are the most abundant with $\mathrm{Ca}$ compounds but the least abundant with Na compounds.

The ratios of $\mathrm{Ca}: \mathrm{Mg}$. $\mathrm{Ca}: \mathrm{K}$ and $\mathrm{Ca}: \mathrm{Na}$ in the sediment and benthic water were the highest at sites above and below the reservoir. The values were lower within the reservoir and decreased with the direction of water flow.

The calcium, magnesium, sodium and potassium compounds bound in the reservoir sediment do not pose a threat to the water environment of the Nysa Szalona valley below the reservoir. The level of the analyzed metals is relatively low and even in the conditions of sudden movement of sediments with water discharged from the reservoir no dangerous water pollution with these compounds would occur.

The examined water from the reservoir and the river is characterised by an appropriate level of exchangeable cations which is required for water used for municipal water supply purposes. The level of these cations in water and deposited in the bottom sediment is also safe enough not to pose a risk to changes in the chemical composition of the test water and for the living organisms inhabiting the reservoir. 


\section{REFERENCES}

BIEL, A. and PASIECZNA, A. 2012. Geochemistry of sediments and water of the Dziećkowice artificial reservoir (Imielińskie lake) southern Poland [in Polish: Charakterystyka geochemiczna osadów i wód zbiornika Dziećkowice (Jeziora Imielińskiego), południowa Polska]. Biul. Państw. Inst. Geol., 450: 1-8.

BOJAKOWSKA, I. and SOKOŁOWSKA, G. 1997. Accumulation of trace elements in lake sediments depending on the zone of their sedimentation [in Polish: Akumulacja pierwiastków śladowych w osadach jeziornych w zależności od strefy ich sedymentacji]. Przegl. Geol., 45(5): 505-508.

BROŚ, K. 1995. Operating instructions for the Stup reservoir on the Nysa Szalona river [in Polish: Instrukcja eksploatacji zbiornika Stup na rzece Nysie Szalonej]. Wrocław: ODGW.

CEM CORPORATION. 1999. Operation manual: MARS 5 Microwave Accelerated Reaction System. Matthews, N.C.: CEM Corporation.

DĄBROWSKA, J. and LEJCUŚ, K. 2012. Characteristics of bottom sediments of the Dobromierz reservoir [in Polish: Charakterystyka osadów dennych Zbiornika Dobromierz]. Infrastruktura $i$ Ekologia Terenów Wiejskich, 3(4): 89-98.

GOMÓŁKA, E. and SZAYNOK, A. 1997. Water and air chemistry [in Polish: Chemia wody i powietrza]. Wrocław: Oficyna Wydawnicza Politechniki Wrocławskiej.

JASIEWICZ, C. and BARAN, A. 2006. Characterization of bottom sediments of two small water retention reservoirs [in Polish: Charakterystyka osadów dennych dwóch zbiorników małej retencji wodnej]. J. Elementol., 11(3): 307-317.

KABATA-PENDIAS, A. and PENDIAS, H. 1999. Biogeochemistry of trace elements [in Polish: Biogeochemia pierwiastków śladowych]. Warszawa: PWN.

KOMOSA, A. 1999. River sediment contamination with plutonium isotopes and heavy metals in Lublin agglomeration (Poland). Pol. J. Environ. Stud., 8(3): 155-160.

KUBIAK, J., TÓRZ, A. and NĘDZAREK, A. 1999. Analytical basics of hydrochemistry [in Polish: Analityczne podstawy hydrochemii]. Szczecin: Wydawnictwo Akademii Rolniczej w Szczecinie.

LIGOCKA, K. and BURCZYK, P. 2018. Preliminary monitoring of macro- and micronutrients in bottom sediments of the Gowienica River [in Polish: Wstępny monitoring makro- i mikroskładników w osadach dennych rzeki Gowienicy]. Ecol. Eng., 19(6): 114-120.

ŁOJKO, R., POLECHOŃSKA, L., KLINK, A. et al. 2015. Trace metal concentrations and their transfer from sediment to leaves of four common aquatic macrophytes. Environ. Sci. Pollut. Res., 22(19): 15123-15131. DOI: 10.1007/s11356-015-4641-1.

MASOUD, M. S., ELEWA, A. S. A., ALI, A. E. et al. 2005. Distribution of some metal concentrations in water and sediments of Lake Edku, Egypt. Bull. Chem. Techn. of Macedonia, 24(1): 21-34.

MINISTRY OF ENVIRONMENT. 2002. Regulation Of The Environment Of 27 November 2002 On Requirements To Be Respected By Surface Waters Used To Supply Population In Water For Consumption [in Polish: Rozporządzenie Ministra Środowiska z dnia 27 listopada 2002 r. w sprawie wymagań, jakim powinny odpowiadać wody powierzchniowe wykorzystywane do zaopatrzenia ludności w wodę przeznaczoną do spożycia]. OJ 2002 No 204, item 1728. Poland.

MINISTRY OF HEALTH. 2017. Health Minister Regulation Of December 7, 2017 On The Quality Of Water Intended For Human Consumption [in Polish: Rozporzadzenie Ministra Zdrowia z dnia 7 grudnia 2017 r. w sprawie jakości wody przeznaczonej do spożycia przez ludzi]. Dz.U. 2017 poz. 2294. Poland.

POLISH COMMITTEE FOR STANDARDIZATION. 1997. Soil quality - determination of ph. PN EN ISO 10390 : 1997. Warszawa: PKN.

POLISH COMMITTEE FOR STANDARDIZATION. 2004. Characterization of sludges - determination of the loss on ignition of dry mass. PN EN 12879 : 2004. Warszawa: PKN.

POLISH COMMITTEE FOR STANDARDIZATION. 2012. Water quality - determination of ph. PN EN ISO 10523 : 2012 . Warszawa: PKN.

PPWIK. 2020. Municipal Water and Sewage Company in Warsaw. [Online]. Available at: https://mpwik. com.pl/ [Accessed: 2020, July 15].

RAFAŁOWSKA, M. and SOBCZYŃSKA-WÓJCIK, K. 2014. The effect of intensive agricultural production on organic matter accumulation in the bottom deposits of Pilawa Bay (Lake Dobskie) [in Polish: Akumulacja materii w osadach dennych Zatoki Pilwa (Jezioro Dobskie) pod wpływem intensywnej produkcji rolnej]. Proc. ECOpole, 8(1): 261-266.

RECZYŃSKI, W. et al. 2006. Distribution of selected heavy metals in bottom sediments of the Dobczycki reservoir. J. Elementol., 11(3): 347-356.

SAMECKA-CYMERMAN, A. and KEMPERS, A. J. 1999. Bioindication of heavy metals by Mimulus guttatus from the Czeska Struga Stream in the Karkonosze Mountains. Poland. Bull. Environ. Contam. Toxicol., 63(1): 65-72. 
SAMECKA-CYMERMAN, A. and KEMPERS, A. J. 2001. Concentration of heavy metals and plant nutrients in water. sediments and aquatic macrophytes of antropogenic lakes (former open cut brown coal mines) differing in stage of acidification. Sci. To.t Environ., 281(1-3): 87-98.

SAMECKA-CYMERMAN, A. and KEMPERS, A. J. 2003. Biomonitoring of water pollution with Elodea canadensis. A case study of three small Polish rivers with different levels of pollution. Water Air Soil. Poll., 145: 139-153.

SAMECKA-CYMERMAN, A. and KEMPERS, A. J. 2004. Toxic metals in aquatic plants surviving in surface water polluted by copper mining industry. Ecotoxicol. Environ. Saf., 59(1): 64-69.

SEJM. 2017. Ustawa z dnia 20 lipca 2017 r. - Prawo wodne. DZ.U. 2017 POZ. 1566. Poland.

SOBCZYŃSKI, T. and JONIAK, T. 2009b. Vertical Changeability of Physical - Chemical Features of Bottom Sediments in Three Lakes in Aspect Type of Water Mixis and Intensity of Human Impact. Pol. J. Environ. Stud., 18(6): 1093-1099.

SOBCZYŃSKI, T. and JONIAK, T. 2009a. Differences in composition and proportion of phosphosrus fractions in bottom sediments of Lake Góreckie (Wielkopolska National Park). Environ. Prot. Eng., 35(2): 89-95.

SZAREK-GWIAZDA, E., GALAS, J., WRÓBEL, A. et al. 2006. Surface sediment composition in an inundated opencast mine (Piaseczno reservoir Southern Poland). Aquatic Ecol., 40: 155-164.

SZULKOWSKA-WOJACZEK, E., and MAREK, J. 1984. Determining the methods and directions of action to limit excessive amounts of chemical compounds entering the waters of the Nysa Szalona and Kaczawa rivers used for supplying drinking water to LGOM [in Polish: Określenie metod i kierunków działania $w$ celu ograniczenia nadmiernych ilości związów chemicznych przedostajacych się do wód rzek Nysy Szalonej i Kaczawy wykorzystywanych do zaopatrzenia w wodę pitna LGOM]. Wrocław: ODGW.

TROJANOWSKI, J. and ANTONOWICZ, J. 2005. Chemical properties of bottom sediments of the Dołgie Wielkie lake [in Polish: Właściwości chemiczne osadów dennych jeziora Dołgie Wielkie]. Stupskie prace biologiczne, 2: 123-133.

VARIAN. 1998. Test procedure. PB-10/I - 1998. Analytical methods company VARIAN.

WÓJCIKOWSKA-KAPUSTA, A., SMAL, H. and LIGĘZA, S. 2018. Contents of selected macronutrients in bottom sediments of two reservoirs and assessment of their suitability for natural use. J. Wat. Land. Develop., 38(7-9): 147-153.

Contact information

Magdalena Senze: magdalena.senze@upwr.edu.pl 